Apart from his own scholarship, Nelson was instrumental in shaping and supporting the research of others. As director of the Institute of Governmental Studies (IGS), Nelson sponsored numerous seminars on topics in American and British government. He established an Overseas Americanist program, providing numerous European and Asian scholars with the opportunity to research American politics at the University of California at Berkeley. His door was always open to graduate students, and they congregated at his table to "pull up a toadstool," listen to him, and just "hang out." Tea time at the IGS was a chance for colleagues and other students to talk to and learn from Nelson.

Nelson served on innumerable prize and program committee for many organizations, including, of course, the American Political Science Association. He was president of the Yale University Council from 1986-1993, and chair of the Presidential Search Committee for the American Academy of Arts and Sciences in 1999-2000. He was greatly respected by the press corps and often quoted in the press. More than that, he was a public intellectual, who engaged regularly in serious intellectual discourse beyond the academy.

His health may have slowed him down physically in the final years, but never slowed his mind. Because he had survived previous health crises, his death caught us by surprise and left us greatly saddened.

Bruce E. Cain University of California, Berkeley

\section{Donald Rothchild}

Professor Donald Rothchild, one the foremost of the students of African international relations, passed away on January 30,2007 , at the age of 78 from complications related to lymphoma.

Donald Rothchild was the author or editor of more than two dozen books and over 70 articles over a career spanning almost 50 years. He wrote perceptibly and with unfailingly exhaustive scholarship on a range of African international relationships, including conflict mediation, international political economy, U.S. foreign policy toward Africa, ethnic politics, international regimes, international security, and Africa's place in contemporary world politics. A scholar of great breadth, he also wrote insightfully in the area of comparative politics as well as important work on Ghana, civil society, Afro-Marxist regimes, statesociety relations, and other topics.

Rothchild was much honored for his high quality and path breaking scholarship. A professor of political science at the University of California, Davis from 1965 until his death, he was awarded a University of California system Distinguished Professorship in 2003. He received fellowships and awards from the Ford Foundation, the Rockefeller Foundation, and the U.S. Institute of Peace. His reputation for quality scholarship won him an international reputation. He taught for a time in four African universities, in Ghana, Zambia, Uganda, and Kenya. He was twice elected to the presidency of an International Political Science Association research committee.

Donald Rothchild's stature as a student of international relations with a particular emphasis on Africa led him to be in great demand as a consultant. He served on numerous editorial boards, including the advisory board to Lynne Rienner Publishers and the Western Political Quarterly. But all this was but the tip of the iceberg. He was constantly in demand for panels at ASA conventions as well as meetings of the International Studies Association, American Political Science Association, and International Studies Association. He was instrumental in the formation of the African Politics Conference Group.

Professor Rothchild was a Phi Beta Kappa graduate of Kenyon College, receiving his M.A. from the University of California, Berkeley, and his Ph.D. from Johns Hopkins University. Before coming to Davis, he taught at Colby College. He met his wife of over 50 years, Edith, during his two years of military service. In addition to Edith, he is survived by two sons, Derek of Hermosa Beach, CA and Maynard of San Marino, CA, and five grandchildren.

Don Rothchild was my great friend, colleague, and collaborator for more than three decades. But he was the great friend, colleague, and collaborator of legions of academics in political science and other fields and in many countries. He exemplified the academic community at its very best. With Don, scholarship and friendship were always seamlessly joined. He was unfailingly generous and unselfish in encouraging the academic pursuits of countless students, colleagues, and collaborators who today support and build the study of international relations. For all of this he will remain a model and an inspiration.

John W. Harbeson City University of New York 